\title{
DOMESTIC-NATIVE GOOSE RELATIONSHIP
}

SIG JORDHEIM, Box 59, White Bear, Saskatchewan. SOL 3LO

During the spring of 1988 , our domestic, brown Chinese-Toulouse gander lost his mate. It so happened that a female Canada Goose, nesting in a basket nest by a dam next to the farm yard, also lost her mate. The female hatched five goslings, and the domestic gander soon joined her in protecting the young. They stayed around the pond by the yard for a few days, then the gander moved, along with his adopted family, to a larger dam located in a coulee $1.2 \mathrm{~km}$ (0.75 mi.) away. In early August, the wild geese were able to fly, and soon left for the south. Our tame gander, unable to join them in flight, came walking home alone.

In the spring of 1989, a female Canada Goose came back to the same nest, but this time a wild gander was with her. Nevertheless, when the young hatched, the tame gander joined the family and all three adults got along very well.

An unusual incident occurred one day which illustrates our goose's involvement with the wild family. A group of bird banders had stopped by and when we came upon these geese some distance from the water, the banders decided to take the opportunity to band the flightless young. As they approached, the parent Canadas immediately took flight. But the domestic gander defended the young, attacking the banders with such ferocity that they were almost forced to give up. However, the five young were successfully banded and later that winter I received word that one had been shot in Nebraska.

The spring of 1990 was a repeat of 1989 , with the domestic gander spending the summer at the big dam with an adopted family of Canada Geese.

The next year, 1991, was much the same, except this time only two eggs hatched. The two goslings looked very much alike until they were about half grown, when we noticed one had orange legs and bill, like the domestic goose, instead of the black legs and bill that a Canada Goose normally has. Later, as it got its feathers, they were light grey, again like the domestic gander, but with the white cheek patch characteristic of the Canada Goose. So, clearly, this youngster was a hybrid.

This family left the area earlier than most of the wild geese, but as soon as they were gone, the domestic gander walked home to rejoin the barnyard flock. 


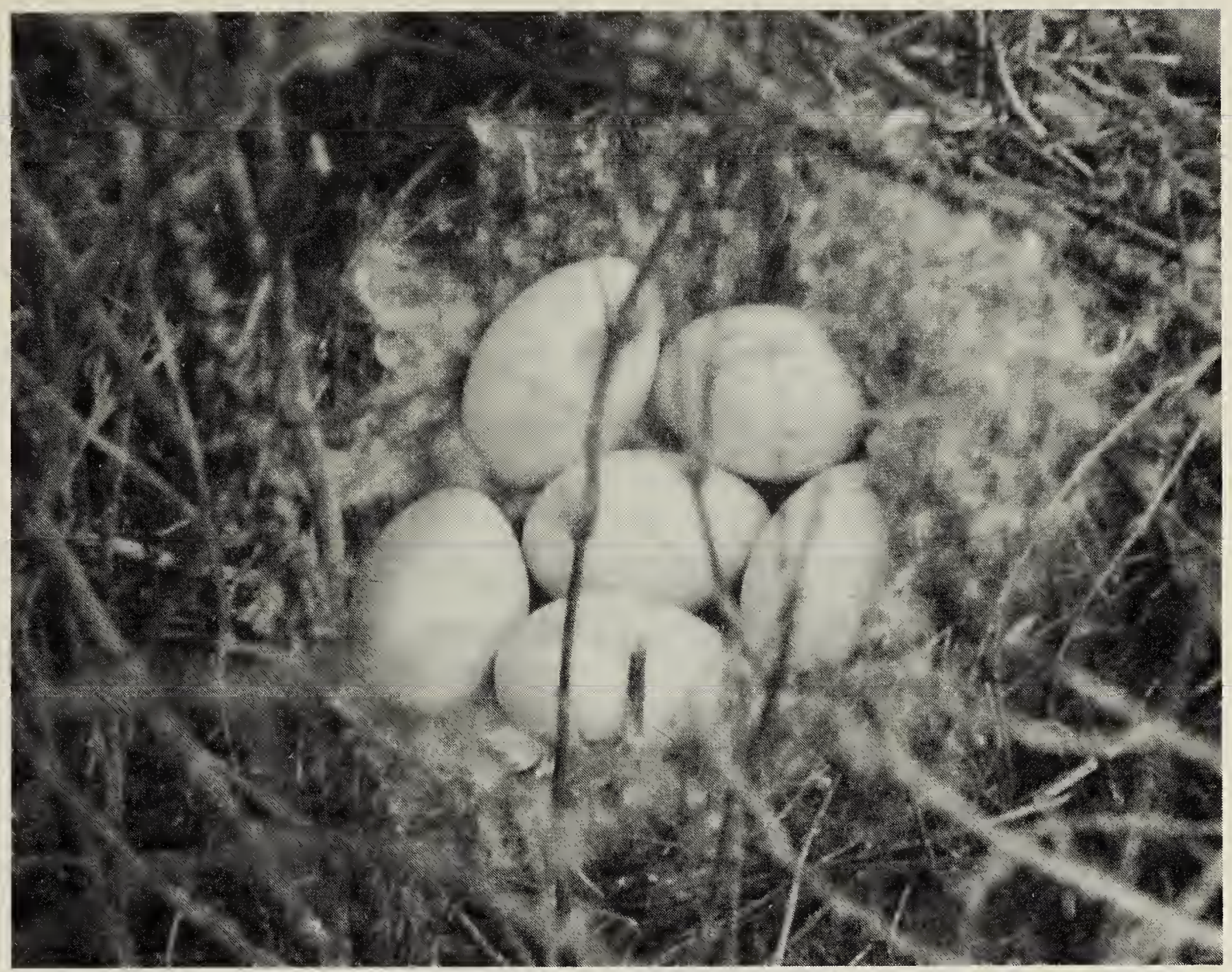

Canada Goose nest.

Daisy D. Meyers

By 1840 the westward movement was confronted with the true prairies of what came to be known as the Middle West. ... The pioneers hesitated on the edge of the large prairies with their seemingly endless expanse of thick grass. There was a sense of vastness about them that seemed overpowering, an impression of greatness that could not be subdued. Indeed, some contended that they would not be brought under cultivation for centuries. E.E. Edwards, 1948. Grass: The Yearbook of Agriculture. Washington.

There are only two dimensions on the plains, time and distance, but they add up to forever. Thin the grass and cut the rainfall in half and the plains become desert, which has still a third dimension, patience. The plains persist. The desert waits. Hal Borland, 1965. Our Natural World. Doubleday, NY. 